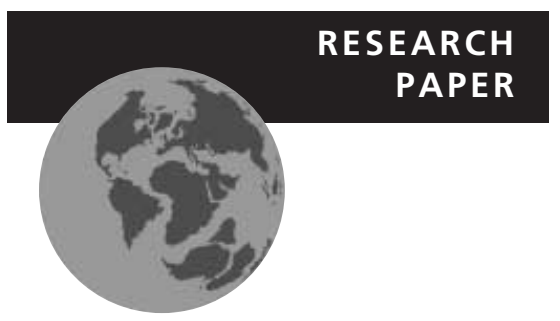

\title{
Will climate change affect ectoparasite species ranges?
}

\author{
Graeme S. Cumming ${ }^{1 \star} \dagger$ and Detlef P. Van Vuuren ${ }^{2}$
}

${ }^{1}$ Department of Wildlife Ecology and Conservation, University of Florida, Gainesville, FL 32611-0430, USA and ${ }^{2}$ MNP, Netherlands Environmental Assessment Agency, PO Box 303, 3720 AH Bilthoven, The Netherlands
${ }^{*}$ Correspondence and current address: Graeme S. Cumming, Percy FitzPatrick Institute of African Ornithology, University of Cape Town, Rondebosch 7701, Cape Town, South Africa.

E-mail: graeme@botzoo.uct.ac.za

\section{ABSTRACT}

Aim Over the next 100 years, human-driven climate change and resulting changes in species occurrences will have global impacts on biodiversity, ecosystem function, and human health. Here we examine how climate change may affect the occurrences of tick species in Africa and alter the suitability of habitat outside Africa for African ticks.

Location Africa and the world.

Methods We predicted continental and global changes in habitat suitability for each of 73 African tick species, using multiple regression models in different climate change scenarios that cover a wide range of uncertainty.

Results Global habitat suitability improves for nearly all tick species under each of a representative range of eight climate change scenarios. Depending on the scenario, African tick species experience an average increase in global habitat suitability of between 1 million and 9 million square kilometres between 1990 and 2100 .

Main conclusions The potential for successful translocations of ticks and their pathogens from Africa to the rest of the world is likely to increase over the next 100 years. Although the general trend is one of range expansion, there are winners and losers among tick species in each scenario, suggesting that tick community composition will be disrupted substantially by climate change. If this is also typical of other invertebrates, then climate change will disrupt not only the geographic location of communities but also their structure. Changes in tick communities are also likely to influence tick-borne pathogens.

\section{Keywords}

Biodiversity, biogeography, climate change, disease, Ixodidae, scenario, species invasions, ticks.

\section{INTRODUCTION}

Both the rate and the number of global species introductions are currently increasing. Species introductions are related closely to trade (Perrings et al., 2002; Levine \& D'Antonio, 2003; Drake \& Lodge, 2004), and at the global scale continued increases in trade are virtually inevitable as the human population expands. Introduced species have already altered food production, the provision of water, the rate and nature of regeneration of woodlands, the provision of wood and non-timber forest products, and the costs of developing and maintaining infrastructure (Mack et al., 2000). These impacts are costly. Pimentel et al. (2001) estimated that species invasions in just six countries (United States, United
Kingdom, Australia, South Africa, India, and Brazil) cause damages of over US $\$ 314$ billion per year. In the United States alone, control of invasive species costs over $\$ 138$ billion per year (Pimentel, 2001).

Global changes in ecosystems will affect the emergence and spread of disease (Daily \& Ehrlich, 1996). The global occurrence of pathogens is linked closely to both climate and the occurrence of vector species (Guernier et al., 2004). Parasite species that carry harmful pathogens in their native ranges seem very likely to do the same in new environments. Although many specialist parasites have life cycles that rely on particular host species, and thus are likely to invade only after particular host introductions have already occurred, generalist parasites such as ticks, mosquitoes and biting flies are not limited in this way; indeed, tick invasions 
from Africa to the Caribbean (and other parts of the world) have already been documented (e.g. Pegram et al., 1996).

Generalist parasites could have a variety of direct and indirect impacts on ecosystems that they invade. They have the potential to alter disease transmission cycles, opening up new realms to emerging diseases. Parasite control is often expensive and difficult, and eradication of generalist parasites is virtually impossible in large areas. Most parasite invasions will be irreversible, demanding sustained expenditure over indefinitely long periods of time. Consequently, generalist parasites represent a group of special concern in the context of invasive species and climate change.

The literature on climate change and vector-borne diseases has been dominated by studies of mosquitoes, which can transmit the pathogens that cause malaria and dengue fever. Studies of mosquitoes have used both mechanistic (Martens et al., 1999) and statistical (Rogers \& Randolph, 2000) approaches. These studies suggest that although there may be an increase in the number of people at risk, little overall change in mosquito distributions is likely. Only a few studies have considered the possible impacts of climate change on tick-borne diseases such as Lyme disease and tick-borne encephalitis (Randolph et al., 2000; Randolph \& Rogers, 2000; McMichael \& Githeko, 2001). There has been no previous research into the possibility of global range expansions by ticks, a group that is of extremely high economic and medical importance for livestock and humans.

The community composition of ticks is central to the epidemiology of tick-borne diseases. For example, the relative abundance of Hyalomma ticks is the primary determinant of epidemic transmission of Crimean-Congo haemorrhagic fever (CCHF) virus (Wilson et al., 1990). Invasions from the diverse African and Asian tick faunas into new areas could have large impacts on the global economy. In 1979 it was estimated that over US\$7 billion a year were being spent on acaricides worldwide (McCosker, 1979); this figure must now be considerably higher. Ticks are vectors of a wide range of human and livestock diseases, including Lyme disease, tick-borne encephalitis, West Nile virus, Q fever, CCHF, a range of rickettsias (including Rocky Mountain Spotted fever), ehrlichiosis, babesiosis (heartwater), theileriosis (also called corridor disease or East Coast fever), cowdriosis and anaplasmosis (Walker et al., 2000). The feeding activities of ticks can cause toxicosis, can affect the quality of cattle hides, and can create wounds that allow entry for screw-worms and other parasites. Invasions by ticks and their pathogens could also have severe economic impacts on the beef, poultry and milk industries, and on revenue-generating activities (such as tourism and hunting) that depend on people being able to obtain safe access to ecosystems. Maes et al. (1998) anticipated an annual cost of US\$500,000 in the United States for therapeutic interventions relating to Lyme disease alone, and over the period 1992-95, laboratories in the state of Maryland spent around US\$7.1 million on serological testing for the Lyme pathogen (Strickland et al., 1997). These figures exclude the potentially high losses associated with reductions in outdoor activities by residents of Lyme-endemic areas, and the effective decrease in value of aesthetic and cultural ecosystem services that has occurred as a consequence of public fears over the possibility of contracting Lyme disease.
The distributions of many invertebrates are known to be regulated by temperature and rainfall (Allen et al., 2002). Many of the tick species that have high economic impacts are extreme generalists (Cumming, 1998; Walker et al., 2000) that could be supported by livestock and indigenous mammals, birds and reptiles in virtually any country in the world. The weight of evidence suggests that at very broad scales, rainfall and temperature (rather than alternative drivers such as host occurrences, soil type or vegetation) are the primary determinants of tick species ranges (Cumming, 1999, 2000a, 2002). At smaller scales, there is also strong evidence for the regulatory role of climate as a driver of tick population abundances (Londt \& Whitehead, 1972; Walker, 1974; Randolph, 1997; Randolph \& Rogers, 1997; Randolph et al., 2000; Rogers \& Randolph, 2003).

In this paper we consider the current and future potential for invasions of ticks (Acari: Ixodida) from Africa to other locations, on the basis of current and projected climatic conditions. The projected climatic conditions explore a substantial part of the current uncertainty regarding climate change in the 21 st century. We apply a set of published, multivariate logistic regression models of tick occurrences (Cumming, 2000c, 2002) to evaluate how global habitat suitability for 73 species of African tick may change over the next 100 years. Although correlative models have their weaknesses, they can 'provide a useful first approximation to the potentially dramatic impact of climate change on biodiversity' (Pearson \& Dawson, 2003; Araújo et al., 2005), particularly when applied at broad scales. The results show that habitat suitability for most African tick species increases both within Africa and globally in all scenarios. Given the burden that invasive ticks could place on economies, the development of more rigorous policies for the control of accidental transfers of ticks between continents is of increasing urgency as chance translocations are increasingly likely to result in successful invasions.

\section{METHODS}

\section{Climate data}

According to the Third Assessment Report of the International Panel on Climate Change (IPCC), climate change in the period 1990-2100 could result in an increase in the global annual mean surface temperature of $1.4-5.8^{\circ} \mathrm{C}$ under a set of climate policyfree scenarios (IPCC, 2001). Broadening the range of scenarios considered to include those with climate policies (Swart et al., 2002; Van Vuuren et al., 2003) lowers the lower range of future climate change to around $1.0{ }^{\circ} \mathrm{C}$ over 1990 levels. Uncertainty in future greenhouse gas emissions and uncertainty in global mean temperatures both increase for a given greenhouse gas concentration (climate sensitivity) and contribute to this range. Projections of local temperature change are even more uncertain. Although global circulation models (GCMs) agree on some of the overall patterns of future climate change (e.g. they generally show greater temperature increases at higher latitudes), they show clearly distinct patterns for temperature increases and even more so for precipitation changes (Cubash \& Meehl, 2001). 
Table 1 Summary of climate scenarios considered. In the eight scenarios that were developed using the IMAGE 2.2 model, three variables were altered to explore the uncertainties of current climate change projections for distribution of African ticks. In most runs, greenhouse gas emissions were assumed to follow the IMAGE implementation of the IPCC Alb scenario, while in two runs a lower (B1) and higher (A1f) emission level was assumed (IMAGE Team, 2001a,b). The four different GCM patterns used in the pattern analysis were taken from the IPCC distribution centre. 'Temperature and precipitation patterns' refers to the annual mean patterns generated by general circulation climate models (GCCM) used in downscaling the global IMAGE results. The abbreviations correspond to the names of the specific GCM models and their results. CGCM1 (Canadian) Coupled Global Climate Model; CSIRO Mark 2, Commonwealth Scientific and Industrial Research Organization (Australia) Model, mark II; ECHAM4, atmospheric model jointly developed by the European Centre for Medium-Range Weather Forecasts and the Max Planck Institute for Meteorology in Hamburg; HADCM2, Hadley Centre Climate Model version 2 (UK)

\begin{tabular}{|c|c|c|c|c|c|c|c|c|}
\hline & 1 & 2 & 3 & 4 & 5 & 6 & 7 & 8 \\
\hline Emissions & Alb & Alb & $\mathrm{Alb}$ & Alb & Alb & $\mathrm{A} 1 \mathrm{~b}$ & Alf & B1 \\
\hline Climate sensitivity $\left({ }^{\circ} \mathrm{C}\right)$ & 2.5 & 2.5 & 2.5 & 2.5 & 4.5 & 1.5 & 4.5 & 1.5 \\
\hline Temperature and precipitation patterns & CGCM1 & CSIRO MK2 & ECHAM4 & HADCM2 & HADCM2 & HADCM2 & HADCM2 & HADCM2 \\
\hline $2100 \mathrm{CO}_{2}$ concentration (p.p.m.v.) & 755 & 755 & 755 & 755 & 775 & 747 & 916 & 512 \\
\hline $\begin{array}{l}2100 \text { Global mean temp. increase }\left({ }^{\circ} \mathrm{C}\right) \\
\text { compared to pre-industrial levels }\end{array}$ & 3.1 & 3.1 & 3.1 & 3.1 & 4.7 & 1.9 & 5.0 & 1.1 \\
\hline
\end{tabular}

In this paper we use a set of climate scenarios developed using the IMAGE 2.2 (Integrated Model to Assess the Global Environment, version 2.2) model. IMAGE 2.2 is a global integrated assessment model that was developed to explore elements of the causal chain of global environmental change (Alcamo et al., 1998; IMAGE Team, 2001b). It combines different submodels, including a global energy model, a global agricultural model, impacts of climate change on natural ecosystems, and a simple climate model. Most of the environmental calculations in IMAGE are performed on a $0.5 \times 0.5$-degree grid, while socio-economic parameters are calculated for 17 world regions. The model includes a state-ofthe-art representation of emissions, capturing all of the relevant greenhouse gases. The climate model used by IMAGE is a slightly altered version of the MAGICC model, which has also been used extensively by the IPCC (2001) to make its assessments of future climate change (Wigley \& Raper, 2001; Eickhout et al., 2004). This simple climate model is used to calculate changes in global mean temperature. Changes in temperature and precipitation are then estimated at a scale of $0.5 \times 0.5$ degrees of longitude/ latitude using the standard IPCC approach to pattern scaling (Carter et al., 2001) and including the revisions proposed by Schlesinger et al. (2000) for the impact of sulphate aerosols.

To explore the potential impacts of climate change on the distributions of African ticks, we explored eight different scenarios (Table 1) developed in the Image 2.2 model. The scenarios are the IMAGE 2.2 implementations of the IPCC's Special Report on Emissions Scenarios (SRES), which is the latest set of IPCC scenarios (Nakicenovic \& Swart, 2000). All scenario details are available electronically (IMAGE Team, 2001a,b). Three cases represent the implementation of the SRES Alb scenario by the IMAGE 2.2 model (IMAGE Team, 2001b), assuming climate sensitivities of $2.5,1.5$ and $4.5^{\circ} \mathrm{C}$, respectively (covering the reported range of uncertainty on climate sensitivity by IPCC, 2001). As climate patterns, these scenarios use the HadCM-2 pattern (Hadley Centre for Climate Prediction and Research, Circulation Model-2) to scale down changes in global mean temperature to the grid level [data obtained from the IPCC
Distribution Centre (IPCC 1999)]. The Alb scenario represents a medium-high emission scenario. We have therefore added two cases, one using the lowest IPCC emission scenario (B1) under a low $\left(1.5^{\circ} \mathrm{C}\right)$ climate sensitivity (representative of a low climate change scenario) and one using the highest IPCC emission scenario (A1f) under a high $\left(4.5^{\circ} \mathrm{C}\right)$ climate sensitivity (representative of a high climate change scenario). We also explored the impact of our central case (A1b, medium climate sensitivity) under different spatial patterns of climate change by using the patterns from three other GCMs, ECHAM4 (European Center for Medium Range Weather Forcasting), CGCM1 (Coupled Global Climate Model of the Canadian Center for Climate Modelling and Analysis), and CSIRO (Commonwealth Scientific and Industrial Research Organization) MK2, again obtained from the IPCC data distribution centre.

Although more recent GCM model runs are available, the pattern scaling method ensures that the scenarios considered here are consistent with the range of recent outcomes in literature (as global mean temperature is calculated using the latest IPCC scenarios, and the patterns used are representative of current uncertainty in local climate change). An important advantage of using these patterns is that they have been applied in many other studies and assessments, including the recently published Millennium Ecosystem Assessment (MA). This means that the implications of changes in tick occurrences can be considered within the detailed social and economic contexts that are outlined in each of the MA scenarios.

\section{Tick data}

The tick data were derived from a large, published, and freely available database of African tick occurrences (Cumming, 1998, 2002). The database contains c. 35,000 individual distribution records for African species and is accurate to a spatial resolution of approximately 0.16 degrees. It was assembled from a wide range of published sources and contains the kinds of bias that might be expected in this kind of data; ticks are sampled unevenly in 
different countries, cattle have been disproportionately sampled relative to wild hosts, and some identifications are unreliable (Cumming, 1998, 2002). Nonetheless, the large number of data points compensates for many of these weaknesses, particularly when undertaking a relatively coarse-grained analysis such as this one. Sufficient occurrence data for producing continental-scale species range models are available for 73 different species. The species considered, their prevalence in the training data, and statistics indicating the fit of each model are listed in Table 2. The distribution maps for individual species, the logic behind the use of climate data for predicting tick species occurrences, and tests of alternative broad-scale factors as determinants of tick occurrences have been published previously (Cumming, 1998, 1999, 2000a,b,c, 2002).

\section{Analysis}

There has been considerable debate over what constitutes the best approach to statistical models of species occurrences (e.g. Austin, 2002; Loiselle et al., 2003; Segurado \& Araújo, 2004; Guisan \& Thuiller, 2005). In undertaking this analysis, we decided to use a statistical approach (multiple regression) that is transparent and widely accepted (see discussions by Fielding \& Bell, 1997; Pearson \& Dawson, 2003; Segurado \& Araújo, 2004; Guisan \& Thuiller, 2005). Scenario development is slightly different from standard predictive science. When contrasting scenarios, the aim is to span the range of uncertainty surrounding projections in a way that is intelligible to end users and easy to repeat, rather than to produce a single 'best' prediction that is treated subsequently as the truth. We decided to avoid approaches that tend to overfit data, those that incorporate some form of black box, and those that require specialized software or have not been widely applied and tested in the literature across a wide range of data sets. Because multiple regression is effective, interpretable, has welldocumented strengths and weaknesses, and has already been shown to fit our particular data extremely well, the use of GLMs (general linear models) matched our criteria better than alternative approaches. This assumption is supported by Segurado \& Araújo (2004), who have argued that GLMs will be most appropriate for species that show relatively simple response curves to environmental gradients, as ticks seem to do at this scale of analysis. In addition, Guisan \& Thuiller (2005) point out that models with a coarse resolution and broad extent are generally less likely to be confounded by such factors as species interactions and habitat fragmentation.

The climate data from 1990 were therefore used to develop a simple logistic regression model for each species individually, based on a published modelling approach and data set (Cumming, 2000c). The tick data were resampled at the resolution of a (far coarser) IMAGE cell to produce estimates of tick presence or absence for each species in each IMAGE cell in Africa. We used mean monthly rainfall and temperature data for odd-numbered months of the year (January, March, May, July, September, November) and the occurrences of each species within Africa. The use of alternate months reduces the degree of temporal autocorrelation in the data as well as reducing the total number of predictor variables and associated measurement errors. Each species occurrence model was trained using exactly the same 12 variables, at the grain of IMAGE cells and the extent of continental Africa, with only species occurrences (the $Y$ variable) being altered. The few models that might be considered overfitted, those for species with relatively low prevalences, tend to be extremely conservative when the $95 \%$ criterion (described below) is applied and hence add few or no potentially false positives. All models fitted the data significantly better than expected by chance and were robust under a bootstrapped test of the area under the curve (AUC) statistic (Table 2).

Once the 1990 models had been developed, we used them to predict the future range of each tick species. The 2100 climate data for each scenario were entered into the model and changes in the response variable (species occurrence) were estimated. The output of each logistic regression model is a probability value that indicates how likely it is that the tick species occurs in each IMAGE cell. For the purposes of this exercise, we needed to transform these values to a simple presence/absence value so that we could estimate changes in species ranges. The probability values given by logistic regression are affected by prevalence (Cumming, 2000b; Olden et al., 2002) and do not show a normal distribution of errors (Olden et al., 2002), so applying a single threshold probability value of 0.5 to determine presence or absence is inappropriate. Instead, we determined presence or absence by taking as a threshold value the probability in the 1990 model that included $95 \%$ of known presences. The threshold value thus varied in a consistent and conservative manner between species, accounting for the effects of prevalence on probability values.

We did not attempt to compensate for differences between northern and southern hemisphere climates in our analysis. The difficulty with trying to do so is that climatic variation does not map simply from south to north, given the extremely broad extent of this analysis, and determining what constitutes biological equivalence for each of 73 species would lead to a messy set of subjective decisions. This weakness has little influence on our conclusions, for two main reasons. First, it makes our predictions of changes in habitat suitability more rather than less conservative; there may be northern hemisphere locations where southern hemisphere ticks could survive, but are not predicted to do so, and vice versa. Consequently, our conclusion that the area of suitable habitat for ticks is likely to increase substantially in the next 100 years is more likely to be understated than overstated. Secondly, the species that are most likely to invade other locations are those that are cosmopolitan within Africa, and as the distributions of these species cover both northern and southern hemispheres, the most relevant models are fitted to both climate regimes.

Changes in tick habitat suitability were quantified by subtracting the 1990 maps from the 2100 maps. We examined changes in the occurrence of individual species and changes in biodiversity under each of our eight scenarios (Table 1). Due to space constraints, only the most important maps are included in the body of this paper. While the results are based on broad-scale correlations rather than immediate mechanisms, and must be interpreted accordingly, broad-scale distribution maps are also relatively robust to changes in smaller-scale variation (which in 
Table 2 The 73 species of African tick considered in the analysis, their prevalence (total number of IMAGE cells that were scored as presences for the original occurrence data), and the Nagelkerke's $r^{2}$ and AUC (area under the curve of a threshold receiver operating characteristic plot) values for each model. The 'AUC1' column contains the AUC obtained for the full original data set ( $n=10,319$; the full set was used to predict tick occurrences in the analysis). The 'AUC2' and 'SD' columns report the mean and standard deviation of a bootstrapped validation of the AUC statistic (these results are from 500 iterations of samples chosen randomly from the original data, with replacement). As discussed in the text, model accuracy is slightly lower for species where the prevalence is low, but this loss of accuracy is balanced by the conservative nature of the process of presence/absence determination. The tick occurrence data and supporting documentation can be obtained from the first author's website

\begin{tabular}{|c|c|c|c|c|c|}
\hline Tick species & Prevalence & Nagelkerke's $r^{2}$ & AUC1 & AUC2 & $\mathrm{SD}$ \\
\hline Amblyomma cohaerens Donitz & 133 & 0.324 & 0.93 & 0.91 & 0.009 \\
\hline A. cuneatum Neumann & 53 & 0.297 & 0.94 & 0.88 & 0.022 \\
\hline A. gemma Donitz & 218 & 0.279 & 0.89 & 0.86 & 0.011 \\
\hline A. hebraeum Koch & 273 & 0.494 & 0.96 & 0.95 & 0.004 \\
\hline A. lepidum Donitz & 224 & 0.191 & 0.86 & 0.85 & 0.01 \\
\hline A. marmoreum Koch & 120 & 0.29 & 0.92 & 0.88 & 0.014 \\
\hline A. nuttalli Donitz & 127 & 0.14 & 0.82 & 0.79 & 0.016 \\
\hline A. paulopunctatum Neumann & 44 & 0.212 & 0.91 & 0.83 & 0.038 \\
\hline A. pomposum Donitz & 106 & 0.358 & 0.95 & 0.93 & 0.008 \\
\hline A. rhinocerotis De Geer & 98 & 0.237 & 0.86 & 0.83 & 0.023 \\
\hline A. sparsum Neumann & 141 & 0.222 & 0.86 & 0.84 & 0.015 \\
\hline A. splendidum Giebel & 81 & 0.247 & 0.92 & 0.89 & 0.014 \\
\hline A. tholloni Neumann & 212 & 0.202 & 0.86 & 0.85 & 0.008 \\
\hline A. variegatum (Fabricius) & 1027 & 0.217 & 0.8 & 0.8 & 0.006 \\
\hline Aponomma exornatum (Koch) & 159 & 0.136 & 0.81 & 0.8 & 0.014 \\
\hline A. latum (Koch) & 170 & 0.137 & 0.81 & 0.8 & 0.012 \\
\hline Boophilus annulatus (Say) & 189 & 0.19 & 0.85 & 0.83 & 0.014 \\
\hline B. decoloratus (Koch) & 1175 & 0.261 & 0.82 & 0.81 & 0.005 \\
\hline B. geigyi Aeschlimann \& Morel & 105 & 0.356 & 0.95 & 0.93 & 0.008 \\
\hline B. microplus (Canestrini) & 178 & 0.369 & 0.94 & 0.93 & 0.007 \\
\hline Dermacentor circumguttatus Neumann & 78 & 0.192 & 0.88 & 0.85 & 0.02 \\
\hline D. rhinocerinus (Denny) & 117 & 0.205 & 0.84 & 0.8 & 0.02 \\
\hline Haemaphysalis aciculifer Warburton & 130 & 0.194 & 0.85 & 0.82 & 0.015 \\
\hline H. leachi (Audouin) & 741 & 0.254 & 0.84 & 0.83 & 0.006 \\
\hline H. paraleachi Camicas, Hoogstraal \& El Kammah & 69 & 0.22 & 0.9 & 0.85 & 0.024 \\
\hline H. parmata Neumann & 137 & 0.287 & 0.92 & 0.89 & 0.011 \\
\hline H. spinulosa Neumann & 143 & 0.133 & 0.81 & 0.78 & 0.017 \\
\hline Hyalomma albiparmatum Schulze & 122 & 0.366 & 0.96 & 0.95 & 0.006 \\
\hline H. anatolicum excavatum Koch & 67 & 0.284 & 0.92 & 0.87 & 0.023 \\
\hline H. dromedarii Koch & 204 & 0.137 & 0.79 & 0.78 & 0.012 \\
\hline H. impeltatum Schulze \& Schlottke & 250 & 0.103 & 0.75 & 0.74 & 0.014 \\
\hline H. rufipes Koch & 775 & 0.222 & 0.81 & 0.81 & 0.006 \\
\hline H. truncatum Koch & 1032 & 0.263 & 0.83 & 0.82 & 0.006 \\
\hline Ixodes cavipalpus Nuttall \& Warburton & 130 & 0.308 & 0.92 & 0.89 & 0.012 \\
\hline I. cumulatimpunctatus Schulze & 56 & 0.305 & 0.94 & 0.89 & 0.024 \\
\hline I. pilosus Koch & 75 & 0.513 & 0.98 & 0.94 & 0.013 \\
\hline I. rasus Neumann & 57 & 0.201 & 0.89 & 0.85 & 0.032 \\
\hline I. rubicundus Neumann & 44 & 0.463 & 0.97 & 0.92 & 0.023 \\
\hline Margaropus winthemi Karsch & 74 & 0.516 & 0.98 & 0.97 & 0.009 \\
\hline Ornithodoros moubata (Murray) & 173 & 0.166 & 0.83 & 0.82 & 0.015 \\
\hline Otobius megnini (Duges) & 213 & 0.668 & 0.99 & 0.97 & 0.004 \\
\hline Rhipicentor bicornis Nuttall \& Warburton & 47 & 0.345 & 0.89 & 0.89 & 0.004 \\
\hline Rhipicephalus appendiculatus Neumann & 676 & 0.271 & 0.93 & 0.87 & 0.031 \\
\hline R. bergeoni Morel \& Balis & 25 & 0.647 & 0.99 & 0.97 & 0.018 \\
\hline R. capensis Koch & 242 & 0.507 & 0.96 & 0.94 & 0.006 \\
\hline R. complanatus Neumann & 58 & 0.199 & 0.9 & 0.83 & 0.032 \\
\hline R. compositus Neumann & 227 & 0.263 & 0.88 & 0.86 & 0.009 \\
\hline R. cuspidatus Neumann & 41 & 0.288 & 0.94 & 0.87 & 0.03 \\
\hline R. distinctus Bedford & 42 & 0.213 & 0.92 & 0.83 & 0.038 \\
\hline R. evertsi Neumann & 1054 & 0.328 & 0.86 & 0.86 & 0.004 \\
\hline
\end{tabular}


Table 2 Continued

\begin{tabular}{|c|c|c|c|c|c|}
\hline Tick species & Prevalence & Nagelkerke's $r^{2}$ & AUC1 & AUC2 & SD \\
\hline R. exopthalmos Keirans, Walker, Horak \& Heyne & 43 & 0.39 & 0.97 & 0.92 & 0.024 \\
\hline R. humeralis Tonelli-Rondelli & 26 & 0.513 & 0.99 & 0.95 & 0.022 \\
\hline R. kochi Donitz group & 106 & 0.297 & 0.92 & 0.9 & 0.014 \\
\hline R. longus Neumann & 167 & 0.175 & 0.85 & 0.83 & 0.011 \\
\hline R. lunulatus Neumann & 145 & 0.148 & 0.83 & 0.81 & 0.015 \\
\hline R. maculatus Neumann & 86 & 0.368 & 0.95 & 0.9 & 0.017 \\
\hline R. muehlensi Zumpt & 89 & 0.237 & 0.89 & 0.83 & 0.019 \\
\hline R. muhsamae Morel \& Vassiliades & 51 & 0.25 & 0.92 & 0.88 & 0.023 \\
\hline R. nitens Neumann & 22 & 0.831 & 0.99 & 0.98 & 0.07 \\
\hline R. oculatus Neumann & 65 & 0.321 & 0.95 & 0.92 & 0.016 \\
\hline R. praetextatus Gerstacker & 28 & 0.638 & 0.99 & 0.98 & 0.015 \\
\hline R. pravus Donitz & 454 & 0.203 & 0.84 & 0.84 & 0.007 \\
\hline R. pulchellus Gerstacker & 244 & 0.309 & 0.92 & 0.9 & 0.007 \\
\hline R. punctatus Warburton & 97 & 0.331 & 0.94 & 0.91 & 0.014 \\
\hline R. reichenowi Zumpt & 53 & 0.195 & 0.9 & 0.82 & 0.032 \\
\hline R. sanguineus (Latreille) & 906 & 0.119 & 0.73 & 0.73 & 0.011 \\
\hline R. senegalensis Koch & 185 & 0.234 & 0.88 & 0.86 & 0.011 \\
\hline R. simus Koch & 782 & 0.213 & 0.81 & 0.8 & 0.007 \\
\hline R. sulcatus Neumann & 94 & 0.15 & 0.82 & 0.77 & 0.024 \\
\hline R. supertritus Neumann & 64 & 0.218 & 0.89 & 0.82 & 0.033 \\
\hline R. tricuspis Donitz & 219 & 0.179 & 0.83 & 0.81 & 0.01 \\
\hline R. zambeziensis Walker, Norval \& Corwin & 89 & 0.436 & 0.97 & 0.94 & 0.012 \\
\hline R. ziemanni Neumann & 80 & 0.219 & 0.91 & 0.86 & 0.018 \\
\hline
\end{tabular}

this case would include such things as dispersal patterns, host abundance, interspecific interactions, and the degree of urbanization). We note also that this paper is intended as an exploration of potential impacts, rather than a definite prediction of likely change; the arguments in favour of our approach are summarized in Pearson \& Dawson (2003), to which we refer the critical reader.

\section{RESULTS}

The results show that under all scenarios, climatic conditions in both Africa and the rest of the world become more suitable for African ticks (Figs 1 and 2). The only tick species for which global climate suitability showed a mean decrease across all scenarios were Amblyomma pomposum, Ixodes cavipalpus, Rhipicephalus lunulatus and R. punctatus (Fig. 3). No tick extinctions occurred in any of the models. The mean area of globally suitable habitat estimated across all species was 11,898 IMAGE cells, with a standard deviation of 6516 cells. With each IMAGE cell being roughly $50 \times 50 \mathrm{~km}$, this represents a mean area of globally suitable habitat for the average African tick of about 29.7 million square kilometres (by comparison, the earth's total land area is c. 148 million square kilometres; Coble et al., 1987).

The largest increases in suitable area for African ticks occur in those scenarios that experience the strongest climate change, such as the Alf scenario combined with high climate sensitivity (mean species range increase of 3938 IMAGE cells; standard deviation 2679; representing an increase in suitable habitat of $33 \%$, or about 9 million square kilometres); while the lowest increases in suitable area occur for the scenarios that experience the least climate change, such as the B1 scenario with a low climate sensitivity (478 IMAGE cells, standard deviation 617; an increase of $0.5 \%$, or just over 1 million square kilometres). Different climate change patterns would alter not only the total area but also the locations where impacts occur, as can be seen from comparing scenarios 1-4 (Fig. 1).

The areas that are most at risk in the future from African tick invasions are those at similar latitudes to African nations and with climate conditions that are already similar in many ways. These areas include Australia, Latin America, and many of the oceanic islands. The southeastern United States and parts of Asia and Europe also become considerably better habitat for many species under several of the scenarios (Fig. 1). Habitat suitability for African ticks increases in Sumatra and Malaysia in all scenarios; habitat suitability in parts of Florida and Georgia improves in all of the scenarios except the Alb scenario using the ECHAM pattern; and habitat suitability in the southern Caribbean Antilles improves in all scenarios except for the Alb scenario using the CGCM1 pattern.

Although the typical trend is towards range increases, it is interesting to note that even among the Ixodidae there are winners and losers in each scenario (Fig. 3). Interestingly, some of the Hyalomma species that are currently found in the dry environments of northern Africa experience the greatest increases in suitable habitat. Global habitat suitability also improves substantially for many of the vector species that most control efforts focus on (such as A. variegatum, A. hebraeum, Boophilus annulatus, Boophilus decoloratus, Hyalomma truncatum, R. appendiculatus and $R$. evertsi). The differences between species in this analysis 

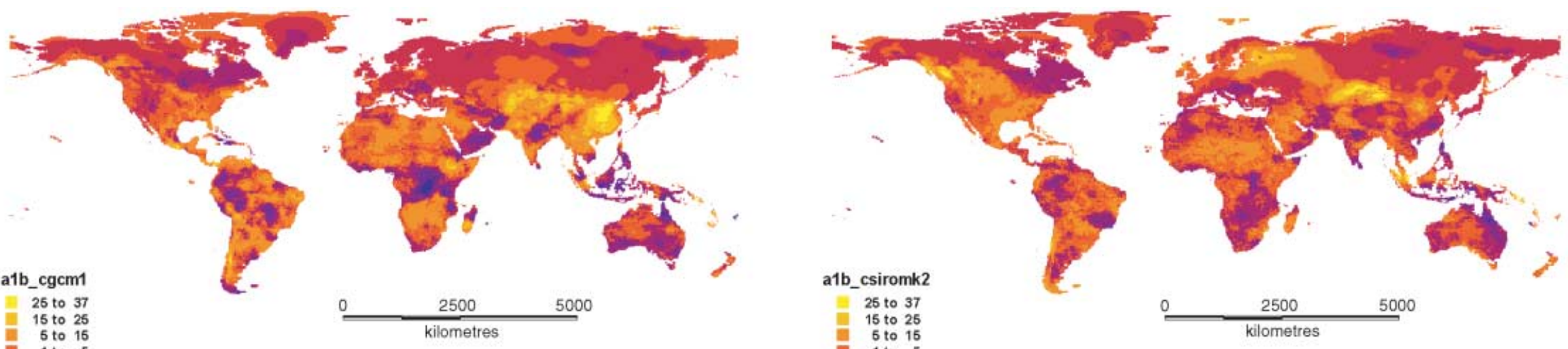

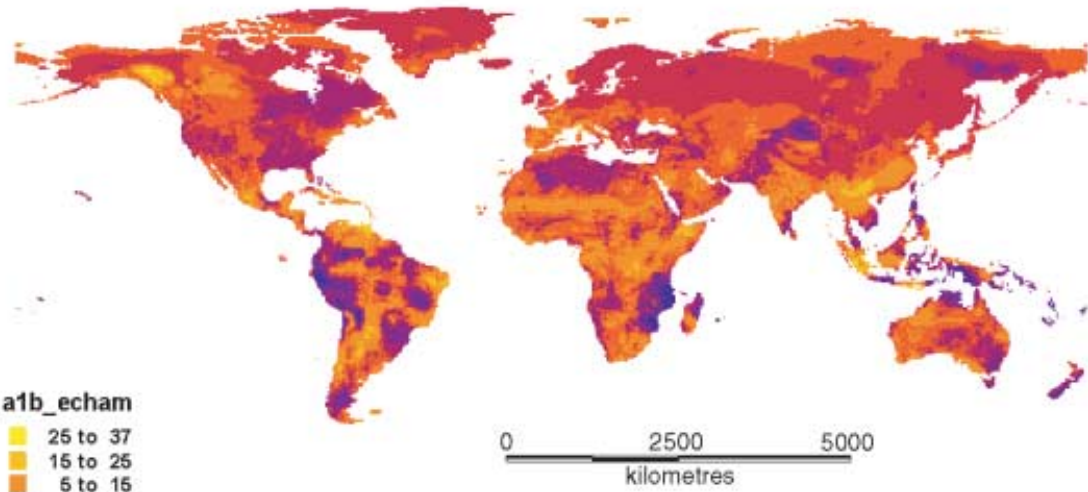

(c)

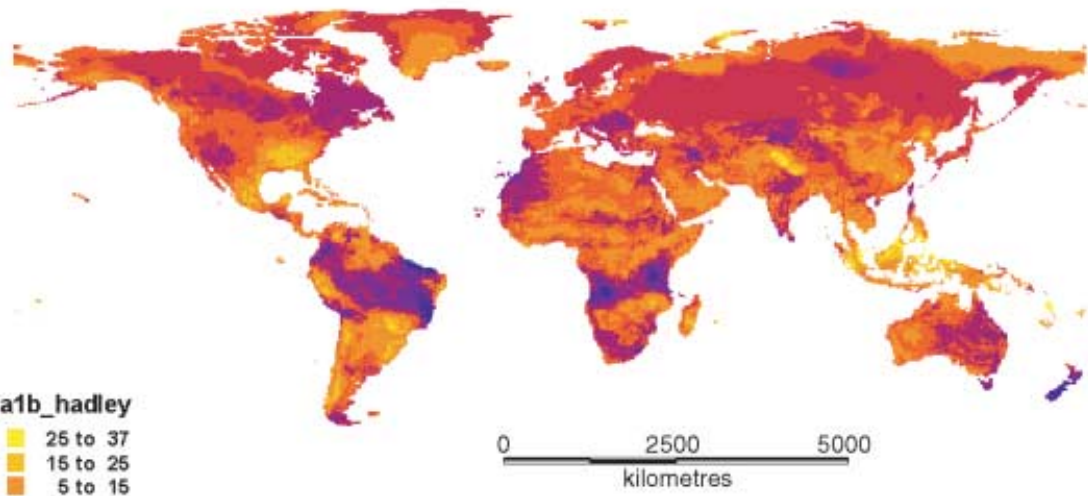

(d)

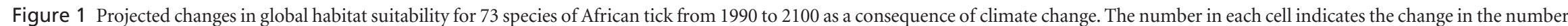

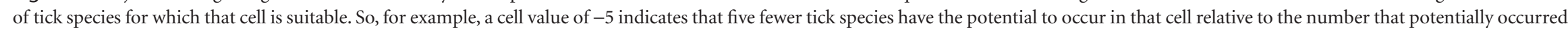
there in 1990. These maps show changes projected by scenarios 1-4 (Table 1), based on A16 with different climate patterns. Additional maps for the other scenarios listed in Table 1 are available from

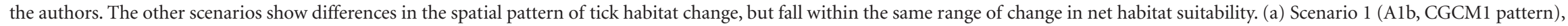
(b) scenario 2 (A1b, CSIRO MK2 patterns), (c) scenario 3 (A1b, ECHAM4 pattern), (d) scenario 4 (A1b, HADCM2 pattern). 
Figure 2 Summary of the net change in total globally suitable habitat for all 73 tick species, relative to a 1990 baseline for all scenarios. The total amount of suitable habitat shows an increase in all scenarios. Each IMAGE cell is roughly $50 \times 50 \mathrm{~km}$.

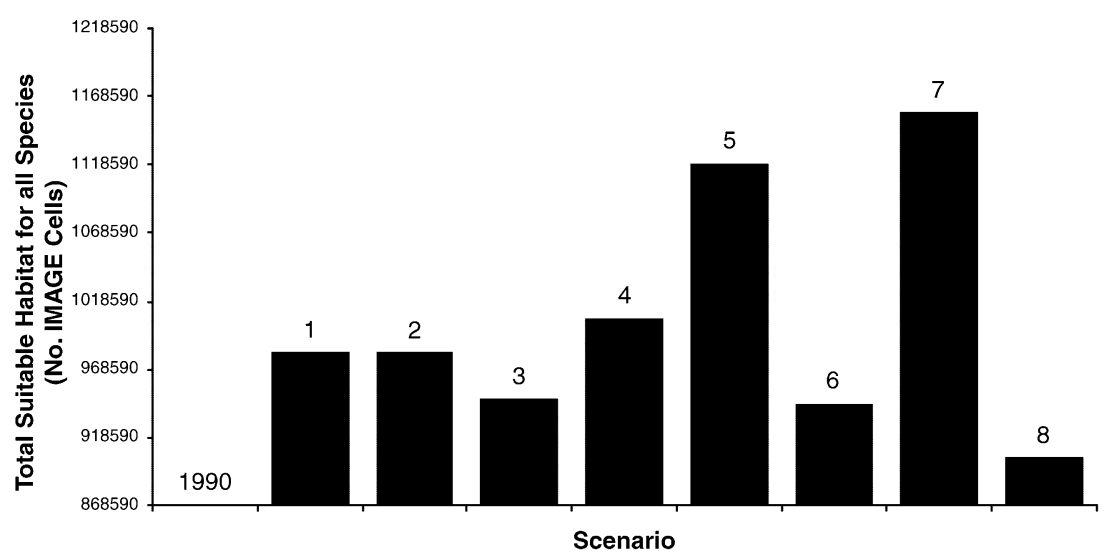

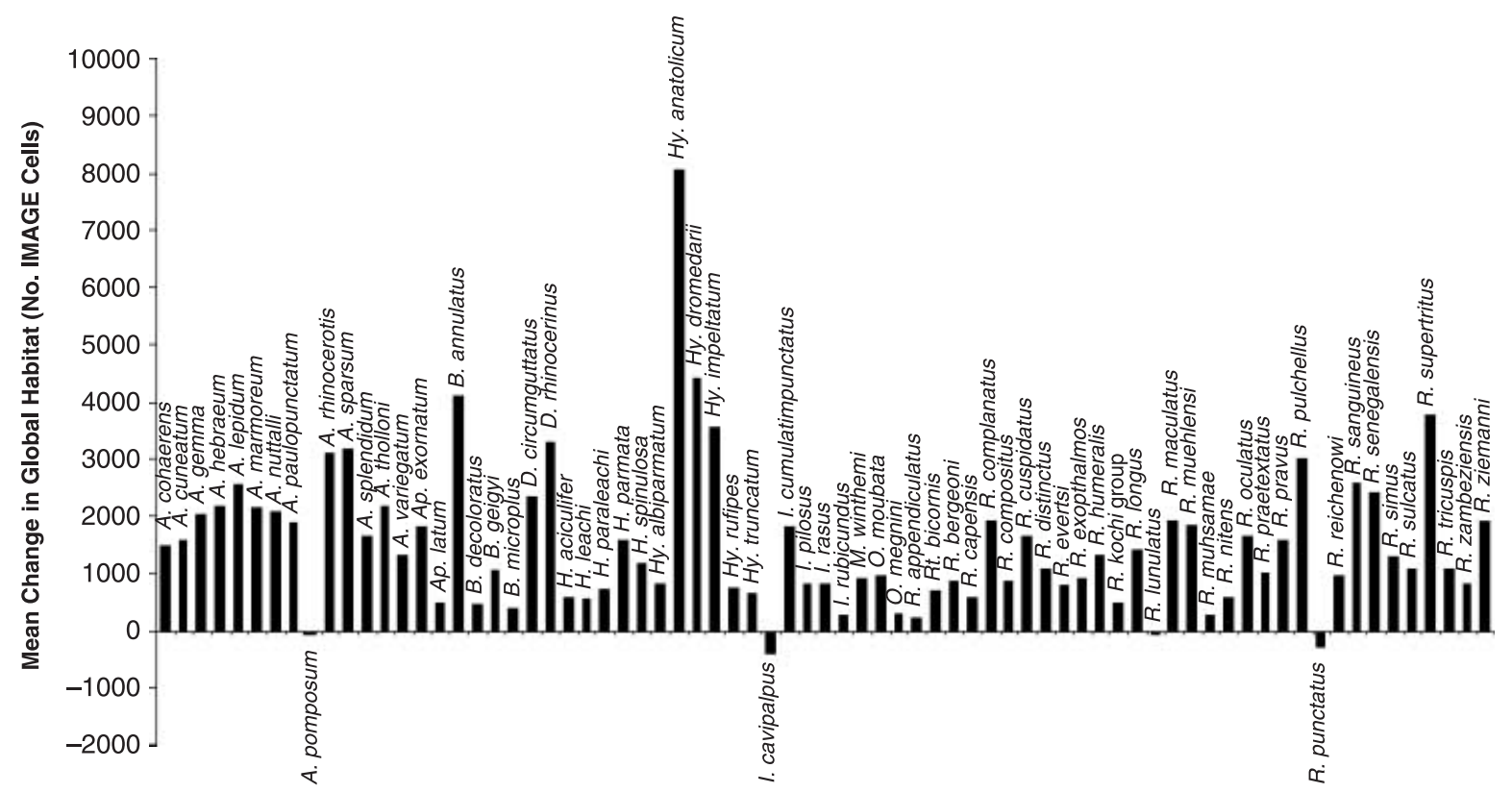

Figure 3 Mean change in global habitat suitability for each of 73 species of African tick from 1990 to 2100 as a consequence of climate change. There are substantial response differences within the Ixodidae, with the northern African desert species Hyalomma anatolicum and H. dromedarii being particularly favoured. These results are an average across all scenarios.

are intriguing and suggest that tick communities may be pulled apart and to some extent reassembled by climate change, potentially leading to different food web dynamics and novel opportunities for emerging pathogens. If such a pattern is typical of invertebrates then the results indicate that climate change will lead to substantial community changes, rather than simply the tracking northwards of climatic conditions that many people have assumed will occur.

\section{DISCUSSION}

The results of the modelling exercise show that under all scenarios, global habitat suitability improves for the vast majority of the 73 African tick species that were included in this analysis. The area of habitat available to our study species increases substantially within Africa and even more so on other continents. Because our analyses cover a representative range of current uncertainty about future changes in the global climate, including relatively low and high emission scenarios and patterns from different GCMs, we can be fairly confident in predicting that global climatic conditions for African ticks will become better rather than worse over the next 100 years. It is also clear that even if effective policies for mitigating climate change were to be implemented, which could result in a similar scenario to our B1 scenario with low climate sensitivity, the risks of invasions by African tick species would still increase. However, our data show that these risks are considerably higher under high climate change scenarios than under low climate change scenarios.

The conclusions of this study make good intuitive sense in light of what is known about tick ecology. Ticks are highly adapted to a life that continually swings between famine and feast. They are vulnerable to desiccation and take longer to reach maturity in 
cold conditions. During favourable periods, tick populations can increase rapidly, and ticks are capable of surviving long periods of adverse conditions by diapausing or finding locally favourable microclimates. The life history and physiological characteristics of African ticks make them well suited to life in a world in which the climate has become warmer and more variable.

Greater habitat suitability within Africa implies not only that ticks will be able to live in more areas, but also that their local abundances will increase in areas that are currently marginal habitat. With increases in total population size and global habitat suitability comes an increasing risk that ticks will be transferred between continents, particularly on traded animals. Ticks appear to be competent dispersers; they can travel long distances on their hosts, and the larvae of many species will feed on migratory birds that travel annually from Africa to Europe and back again (Cumming, 1998).

Our maps of current habitat suitability suggest a high likelihood of several specific invasions that in fact have already occurred. For example, the African tick $A$. variegatum, an important and widespread vector species in Africa, invaded a number of Caribbean islands including Puerto Rico, St Croix, Guadeloupe, Martinique, St Kitts and St Lucia (Uilenberg et al., 1984; Walker \& Olwage, 1987; Pegram \& Eddy, 2002). With assistance from the United States Department of Agriculture (USDA), the tick has since been eradicated from many of these areas at great expense (Pegram \& Eddy, 2002). Eradication of A. variegatum from the small island of Antigua was expected to cost over US\$1.5 million for pesticides alone (Pegram \& Eddy, 2002). The increasing susceptibility of many island nations to invasion by African ticks is of high concern, given the apparently high vulnerability of island faunas to exotic diseases and parasites (Wikelski et al., 2004), and the many rare and endemic species that islands harbour.

Although we have focused on the African fauna, the same trends are likely in other parts of the world and for other arthropod species that are vectors of pathogens. We anticipate that at a global scale there will be an increase in the local abundance and diversity of ticks in many locations by 2100 . In Europe, expansions of tick species ranges over the last 20-30 years have already been reported in Sweden and in the Czech Republic (EEA, 2004), and increases in tick-borne diseases have been reported from countries bordering the Baltic Sea (Sweden, Finland, Poland, Latvia, Estonia, and Lithuania) as well as the central European countries (Switzerland, Germany, Czech Republic, and Slovakia; EEA, 2004), and the Netherlands (den Boon et al., 2004). When placed in the context of a global net increase in trade and the related translocations of host species, further invasions by ticks seem inevitable. A number of worrying trends in tick movements currently exist. Controls on translocations of animals are lax, and few customs facilities will adequately screen animals that are in quarantine. Ticks may travel unobtrusively on vertebrates, hidden under fur, between folds of skin, or in orifices. Potentially harmful or poisonous animals, such as cobras and carnivores, are particularly unlikely to receive thorough inspections (M.J. Burridge, pers. comm.).

Many people are unwilling to accept that dispersal of ticks between continents on translocated animals could lead to tick invasions. However, a number of well-documented examples illustrate the potential for this to occur. For instance, Florida is predicted to become more suitable for ticks under global climate change. The town of Miami in the state of Florida, is currently one of the centres for the global trade in reptiles. Surveys suggest that over a million individual African ticks are imported into Miami every year on snakes and tortoises (Clark \& Doten, 1996). At least one of these individuals has been found to carry antibodies to heartwater, a disease that is one of the scourges of the livestock industry in Africa (M.J. Burridge, pers. comm.). African Amblyomma species exhibit far higher heartwater transmission capabilities than their American congeners (Mahan et al., 2000), and animals in Florida would exhibit little natural resistance. It has been estimated that if the disease were introduced into Florida, one of the largest beef producers in the United States, up to $50 \%$ of infected cattle and $90 \%$ of infected sheep, goats and deer would die of the disease (Burridge, 1997; Burridge et al., 2000). Breeding colonies of the African species A. variegatum and A. marmoreum have already been found in reptile holding centres in Miami (Allan et al., 1998). Exotic ticks have been identified on 29 (91\%) of 32 reptile premises in 18 counties of Florida (Burridge et al., 2000). At least 99 species of non-native tick are known to have been either detected and destroyed at ports of entry or imported into the United States since 1950 (Keirans \& Durden, 2001). A total of 29 tick species have entered the country on reptiles alone since 1962 (Burridge \& Simmons, 2003), and one of the tick species of greatest concern in southern Africa, A. hebraeum, has been recorded entering Florida on a human host (Burridge et al., 2002).

Ultimately, the problem of preventing tick invasions is a small piece in the broader issue of the need to modify incentive structures (Perrings et al., 2002) to achieve appropriate regulation of species translocations. Although the costs of reducing the likelihood of tick invasions may be significant, failure to implement appropriate control measures could be considerably more expensive. Increases in tick abundances will almost certainly alter patterns of tick-borne disease transmission and can be expected to have significant consequences for the health of humans and their livestock.

In addition to their immediate relevance to policy and management, our results have interesting implications in the areas of parasite ecology and the study of invertebrate responses to climate change. While we would have liked to conduct this analysis in a more mechanistic manner, critically little is known about the basic ecology of ticks and many other parasitic species. Research on ticks has focused narrowly on tick-host immune interactions and on the small minority of species that have been considered important vectors of disease-causing pathogens. For instance, basic life history data, such as the number of eggs produced per clutch, hatching success, and adult mortality rates, are unknown for nearly all African tick species. There has also been little research on the relationship between vector community composition and pathogen transmission (Ostfeld \& Keesing, 2000); at present, we do not know whether an invasion by a single abundant, generalist tick species would have the same consequences as multiple invasions of different tick species. The lack of general information on tick physiology and ecology makes it 
difficult to develop mechanistic models to test broad-scale predictions about tick responses to climate change, and the lack of a complete phylogeny makes comparative studies difficult. Further research on basic tick ecology will be essential if we are to develop effective response measures to the threat of tick invasions.

More generally, there is a high likelihood within Africa of changes in the species ranges and biodiversity of ticks. To what degree is this pattern likely to be representative of future trends in invertebrate species ranges and populations? Many invertebrate populations are strongly affected by climate (Allen et al., 2002). Our results suggest that within any single taxon there will be winners and losers over the next 100 years. Although most tick species ranges are predicted to increase in response to climate change, some contract. Regardless of whether the distributions of plant communities are altered, insect pollinators, herbivores, and parasitoids will respond in a variety of differing ways. Consequently, we can expect to see changes in the spatial patterns of invertebrate species ranges and community structures. These effects may have important implications for food production, disease regulation and other kinds of ecosystem service that our society depends upon. Understanding the responses of generalist parasites to climate variation is of high priority if we are to anticipate future climate change-related problems and develop policy and management responses to avoid or mitigate their impacts.

\section{ACKNOWLEDGEMENTS}

We are grateful to the members of the Millennium Assessment Biodiversity Scenarios Group for their intellectual contributions through the many discussions that we have had about climate change and biodiversity. Heidi Richter (at UF) and several colleagues from RIVM/MNP commented on earlier drafts of this manuscript. We also thank other members of the IMAGE team for their assistance in developing the scenarios used in this paper.

\section{REFERENCES}

Alcamo, J., Leemans, R. \& Kreileman, G.J.J. (1998) Global change scenarios of the 21st century: results from the IMAGE 2.1 model. Pergamon \& Elsevier Science, London.

Allan, S.A., Simmons, L.A. \& Burridge, M.J. (1998) Establishment of the tortoise tick Amblyomma marmoreum (Acari: Ixodidae) on a reptile-breeding facility in Florida. Journal of Medical Entomology, 35, 621-624.

Allen, A.P., Brown, J.H. \& Gillooly, J.F. (2002) Global biodiversity, biochemical kinetics, and the energetic-equivalence rule. Science, 297, 1545-1548.

Araújo, M.B., Pearson, R.G., Thuiller, W. \& Erhard, M. (2005) Validation of species-climate impact models under climate change. Global Climate Change Biology, 11, 15041513.

Austin, M.P. (2002) Spatial prediction of species distributions: an interface between ecological theory and statistical modelling. Ecological Modelling, 157, 101-118.

den Boon, S., Schellekens, J.F.P., Schouls, L.M., Suijkerbuijk, A.W.M., Docters van Leeuwen, B. \& van Pelt, W. (2004) Verdubbeling van het aantal consulten voor tekenbeten en Erythema migrans in de huisartsenpraktijk in Nederland. Nederlands Tijdschrift voor Geneeskdunde, 148, 665-670.

Burridge, M.J. (1997) Heartwater: an increasingly serious threat to the livestock and deer populations of the United States. Proceedings of the 101st Annual Meeting of the United States Animal Health Association, Louisville, Kentucky, pp. 582-597. Spectrum Press, Richmond, Virginia.

Burridge, M.J. \& Simmons, L.A. (2003) Exotic ticks introduced into the United States on imported reptiles from 1962 to 2001 and their potential roles in international dissemination of diseases. Veterinary Parasitology, 113, 289-320.

Burridge, M.J., Simmons, L.A. \& Allan, S.A. (2000) Introduction of potential heartwater vectors and other exotic ticks into Florida on imported reptiles. Journal of Parasitology, 86, 700 704.

Burridge, M.J., Simmons, L.A., Simbi, B.H., Mahan, S.M., Fournier, P.E. \& Raoult, D. (2002) Introduction of the exotic tick Amblyomma hebraeum into Florida on a human host. Journal of Parasitology, 88, 800-801.

Carter, T.R., La Rovere, E.L., Jones, R.N., Leemans, R., Mearns, L.O., Nakicenovic, N., Pittock, B.A., Semenov, S.M. \& Skea, J.F. (2001) Developing and applying scenarios. Climate change 2001: impacts, adaptation and vulnerability (ed. by J.J. McCarthy, O.F. Canziani, N.A. Leary, D.J. Dokken and K.S. White), pp. 145-190. Cambridge University Press, Cambridge.

Clark, L.G. \& Doten, E.H. (1996) Ticks on imported reptiles into Miami International Airport: November 1994 through January 1995. Proceedings of a Symposium on Epidemiology and Economics, pp. 2-19. US Government Printing Office, Washington, DC.

Coble, C.R., Murray, E.G. \& Rice, D.R. (1987) Earth science. Prentice-Hall, Englewood Cliffs, NJ.

Cubash, U. \& Meehl, G.A. (2001) Projections of future climate change. Climate change 2001: the scientific basis (ed. by C.A. Johnson), pp. 525-582. Cambridge University Press, Cambridge.

Cumming, G.S. (1998) Host preference in African ticks (Acari: Ixodida): a quantitative data set. Bulletin of Entomological Research, 88, 379-406.

Cumming, G.S. (1999) Host distributions do not limit the species ranges of most African ticks (Acari: Ixodida). Bulletin of Entomological Research, 89, 303-327.

Cumming, G.S. (2000a) Host use does not clarify the evolutionary history of African ticks (Acari: Ixodoidea). African Zoology, $35,43-50$.

Cumming, G.S. (2000b) Using between-model comparisons to fine-tune linear models of species ranges. Journal of Biogeography, 27, 441-455.

Cumming, G.S. (2000c) Using habitat models to map diversity: pan-African species richness of ticks (Acari: Ixodida). Journal of Biogeography, 27, 425-440.

Cumming, G.S. (2002) Comparing climate and vegetation as limiting factors for species ranges of African ticks. Ecology, 83, 255-268. 
Daily, G. \& Ehrlich, P.R. (1996) Impacts of development and global change on the epidemiological environment. Environment and Development Economics, 1, 311-346.

Drake, J.M. \& Lodge, D.M. (2004) Global hot spots of biological invasions: evaluating options for ballast-water management. Proceedings of the Royal Society of London Series B, 271, 575-580.

Eickhout, B., Den Elzen, M.G. \& Kreileman, G.J.J. (2004) The atmosphere-ocean system of IMAGE 2.2. National Institute for Public Health and the Environment, Bilthoven.

European Environmental Agency (EEA) (2004) Impacts of Europe's changing climate: an indicator-based assessment. European Environmental Agency Report No. 2/2004, p. 103. EEA, Copenhagen.

Fielding, A.H. \& Bell, A.J. (1997) A review of methods for the assessment of prediction errors in conservation presence/ absence models. Environmental Conservation, 24, 38-49.

Guernier, V., Hochberg, M.E. \& Guégan, J.-F. (2004) Ecology drives the worldwide distribution of human diseases. PLoS Biology, 2, 740-746.

Guisan, A. \& Thuiller, W. (2005) Predicting species distribution: offering more than simple habitat models. Ecology Letters, 8, 993-1009.

IMAGE Team (2001a) The IMAGE 2.2 implementation of the SRES scenarios. A comprehensive analysis of emissions, climate change and impacts in the 21st century. Main disk. National Institute for Public Health and the Environment, Bilthoven, the Netherlands.

IMAGE Team (2001b) The IMAGE 2.2 implementation of the SRES scenarios. Climate change scenarios resulting from runs with several GCMs. Supplementary disk. National Institute for Public Health and the Environment, Bilthoven, the Netherlands.

Intergovernmental Panel on Climate Change (IPCC) (1999) Data distribution centre for climate change and related scenarios for impacts assessment. University of East Anglia. Data available from http://ipcc-ddc.cru.uea.ac.uk/. Accessed 2001.

Intergovernmental Panel on Climate Change (IPCC) (2001) Climate change 2001: synthesis report. Cambridge University Press, Cambridge.

Keirans, J.E. \& Durden, L.A. (2001) Invasion: exotic ticks (Acari: Argasidae, Ixodidae) imported into the United States. A review and new records. Journal of Medical Entomology, 38, 850-861.

Levine, J.M. \& D’Antonio, C.M. (2003) Forecasting biological invasions with increasing international trade. Conservation Biology, 17, 322-326.

Loiselle, B.A., Howell, C.A., Graham, C.H., Goerck, J.M., Brooks, T., Smith, K.G. \& Williams, P.H. (2003) Avoiding pitfalls of using species distribution models in conservation planning. Conservation Biology, 17, 1591-1600.

Londt, J.G.H. \& Whitehead, G.B. (1972) Ecological studies of larval ticks in South Africa (Acarina: Ixodidae). Parasitology, 65, 469-490.

Mack, R.N., Simberloff, D., Lonsdale, W.M., Evans, H., Clout, M. \& Bazzaz, F.A. (2000) Biotic invasions: causes, epidemiology, global consequences, and control. Ecological Applications, 10 , 689-710.
Maes, E., Lecomte, P. \& Ray, N. (1998) A cost-of-illness study of Lyme disease in the United States. Clinical Therapeutics, 20, 993-1008.

Mahan, S.M., Peter, T.F., Simbi, B.H., Kocan, K., Camus, E., Barbet, A.F. \& Burridge, M.J. (2000) Comparison of efficacy of American and African Amblyomma ticks as vectors of heartwater (Cowdria ruminantium) infection by molecular analyses and transmission trials. Journal of Parasitology, 86, 44-49.

Martens, W.J.M., Kovats, R.S., Nijhof, S., deVries, P., Livermore, M.J.T., McMichael, A.J., Bradley, D. \& Cox, J. (1999) Climate change and future populations at risk of malaria. Global Environmental Change, 9, S89-S107.

McCosker, P.J. (1979) Global aspects of the management and control of ticks of veterinary importance. Recent advances in acarology II (ed. by J.G. Rodríguez), pp. 45-53. Academic Press, New York.

McMichael, A.J. \& Githeko, A. (2001) Human health. Climate change 2001: impacts, adaptation and vulnerability (ed. by J.J. McCarthy, O.F. Canziani, N.A. Leary, D.J. Dokken and K.S. White), pp. 451-485. Cambridge University Press, Cambridge.

Nakicenovic, N. \& Swart, R. (eds) (2000) Special report on emissions scenarios. A special report of Working Group III of the Intergovernmental Panel on Climate Change. Cambridge University Press, Cambridge.

Olden, J.D., Jackson, D.A. \& Peres-Neto, P.R. (2002) Predictive models of fish species distributions: a note on proper validation and chance predictions. Transactions of the American Fisheries Society, 131, 329-336.

Ostfeld, R.S. \& Keesing, F. (2000) The function of biodiversity in the ecology of vector-borne zoonotic diseases. Canadian Journal of Zoology, 78, 2061-2078.

Pearson, R.G. \& Dawson, T.P. (2003) Predicting the impacts of climate change on the distribution of species: are bioclimatic envelope models useful? Global Ecology and Biogeography, 12, 361-371.

Pegram, R.G. \& Eddy, C. (2002) Progress towards the eradication of Amblyomma variegatum from the Caribbean. Experimental and Applied Acarology, 28, 273-281.

Pegram, R.G., Rota, A., Onkelinx, R., Wilson, D.D., Bartlette, P., Nisbett, B.S., Swanston, G., Vanterpool, P. \& deCastro, J.J. (1996) Eradicating the tropical bont tick from the Caribbean. World Animal Review, 56-65.

Perrings, C., Williamson, M., Barbier, E.B., Delfino, D., Dalmazzone, S., Shogren, J., Simmons, P. \& Watkinson, A. (2002) Biological invasion risks and the public good: an economic perspective. Conservation Ecology, 6, 1. Available at: http://www.consecol.org/vol6/iss1/art1/.

Pimentel, D. (2001) Pricing biodiversity and ecosystem services. Bioscience, 51, 270-271.

Pimentel, D., McNair, S., Janecka, J., Wightmann, J., Simmonds, C., O'Connel, C., Wong, E., Russel, L., Zern, J., Aquino, T. \& Tsomondo, T. (2001) Economic and environmental threats of alien plant, animal and microbe invasions. Agriculture, Ecosystems and Environment, 84, 1-20. 
Randolph, S.E. (1997) Abiotic and biotic determinants of the seasonal dynamics of the tick Rhipicephalus appendiculatus in South Africa. Medical and Veterinary Entomology, 11, 25-37.

Randolph, S.E. \& Rogers, D.J. (1997) A generic population model for the African tick Rhipicephalus appendiculatus. Parasitology, 115, 265-279.

Randolph, S.E. \& Rogers, D.J. (2000) Fragile transmission cycles of tick-borne encephalitis virus may be disrupted by predicted climate change. Proceedings of the Royal Society of London Series B, 267, 1741-1744.

Randolph, S.E., Green, R.M., Peacey, M.F. \& Rogers, D.J. (2000) Seasonal synchrony: the key to tick-borne encephalitis foci identified by satellite data. Parasitology, 121, 15-23.

Rogers, D.J. \& Randolph, S.E. (2000) The global spread of malaria in a future, warmer world. Science, 289, 1763-1766.

Rogers, D.J. \& Randolph, S.E. (2003) Studying the global distribution of infectious diseases using GIS and RS. Nature Reviews Microbiology, 1, 231-237.

Schlesinger, M.E., Malyshev, S., Rozanov, E.V., Yang, F., Andronova, N.G., de Vries, B., Grübler, A., Jiang, K., Masui, T., Morita, T., Nakicenovic, N., Penner, J., Pepper, W., Sankovski, A. \& Zhang, Y. (2000) Geographical distributions of temperature change for scenarios of greenhouse gas and sulphur dioxide emissions. Technological Forecasting and Social Change, 65, 167-193.

Segurado, P. \& Araújo, M.B. (2004) Evaluation of methods for modelling species probabilities of occurrence. Journal of Biogeography, 31, 1555-1568.

Strickland, G.T., Karp, A.C., Mathews, A. \& Pena, C.A. (1997) Utilization and cost of serologic tests for Lyme disease in Maryland. Journal of Infectious Diseases, 176, 819-821.

Swart, R., Mitchell, J., Morita, T. \& Raper, S. (2002) Stabilisation scenarios for climate impact assessment. Global Environmental Change, 12, 155-165.

Uilenberg, G., Barre, N., Camus, E., Burridge, M.J. \& Garris, G.I. (1984) Heartwater in the Caribbean. Preventive Veterinary Medicine, 2, 255-267.

Van Vuuren, D.P., Den Elzen, M.G., Berk, M.M., Lucas, P.L., Eickhout, B., Eerens, H. \& Oostenrijk, R. (2003) Regional costs and benefits of alternative post-Kyoto climate regimes. National Institute for Public Health and the Environment, Bilthoven, the Netherlands.

Walker, J.B. (1974) The ixodid ticks of Kenya: a review of present knowledge of their hosts and distributions. Commonwealth Institute of Entomology, Eastern Press, London and Reading.
Walker, J.B., Keirans, J.E. \& Horak, I.G. (2000) The genus Rhipicephalus (Acari, Ixodidae): a guide to the brown ticks of the world. Cambridge University Press, Cambridge.

Walker, J.B. \& Olwage, A. (1987) The tick vectors of Cowdria ruminantium (Ixodoidea, Ixodidae, genus Amblyomma) and their distribution. Onderstepoort Journal of Veterinary Research, 54, 353-379.

Wigley, T.M.L. \& Raper, S.C.B. (2001) Interpretation of high projections for global-mean warming. Science, 293, 451454.

Wikelski, M., Foufopolous, J., Vargas, H. \& Snell, H. (2004) Galapagos birds and diseases: invasive pathogens as threats for island species. Ecology and Society, 9, 5.

Wilson, M.L., Gonzalez, J.P., LeGuenno, B., Cornet, J.P., Guillaud, M., Calvo, M.A., Digoutte, J.P. \& Camicas, J.L. (1990) Epidemiology of Crimean-Congo hemorrhagic fever in Senegal: temporal and spatial patterns. Archives of Virology, Supplement 1, 323-340.

\section{BIOSKETCHES}

Graeme Cumming has recently been appointed to a chair in Conservation Biology at the Percy FitzPatrick Institute at the University of Cape Town, South Africa. Prior to this he was based at the University of Florida. He has published over 30 peer-reviewed research articles and book chapters and is currently co-editing a book on sustainability and complex systems. His primary research interests are in landscape and community ecology, and specifically in the broad-scale relationships between landscape heterogeneity, biological diversity, and ecosystem function.

Detlef Van Vuuren is an environmental scientist working in the IMAGE Integrated Assessment modelling team of the Netherlands Environmental Assessment Agency. His research interests are in developing integrated scenarios of energy use and global environmental change, and he has written more than 30 peer-reviewed articles on these topics. He contributed as a co-ordinating lead-author to the Millennium Ecosystem Assessment and is currently working as a lead author for the IPCC's Fourth Assessment Report and UNEP's Global Environment Outlook.

Editor: Martin Sykes 